Publication Guidelines . . . . . . . . . . . . . 2

Contents ............... 3

Omani Classical Poetry and Discourse Deviation 5 Hilal Al Hajri

Khalid Al Balushi

An Investigation into Assessment Preferences of Gulf Arab Students Mashael Al-Hamly

Christine Coombe 
Sultan Qaboos University Journal of Arts \& Social Sciences

\section{Omani Classical Poetry and Discourse Deviation}

\begin{tabular}{c}
\hline Hilal Al Hajri \\
\hline Assistant Professor \\
Departments of Arabic Language \\
and Literature \\
College of Arts \& Social Sciences \\
Sultan Qaboos University \\
hajri@squ.edu.om
\end{tabular}

\begin{tabular}{c}
\hline Khalid Al Balushi \\
\hline Assistant Professor \\
Departments of English Language \\
and Literature \\
College of Arts \& Social Sciences \\
Sultan Qaboos University \\
khalidb@squ.edu.om
\end{tabular}




\title{
Omani Classical Poetry and Discourse Deviation
}

\author{
Hilal Al Hajri and Khalid Al Balushi
}

\section{Abstract}

We argue in this paper that there are voices in Omani classical poetry that challenged the dominant cultural discourse and deviated from it. The paper is divided into two parts. Part one is mainly theoretical. We start by introducing Omani poetic discourse as one in which different voices compete. We then refer to literary theory to establish that poetry by definition challenges public discourse. Part two is practical. Taking what is established in Part 1 as our point of departure, we practically substantiate our claim by discussing excerpts from Omani classical poetry. We conclude by putting forward suggestions for further study.

Keywords: Discourse, conformity, deviation, norms.

\section{الشعر الكلاسيكي العماني و الانحراف الخطابي}

\author{
هلال الحجري و خالد البلوشي
}

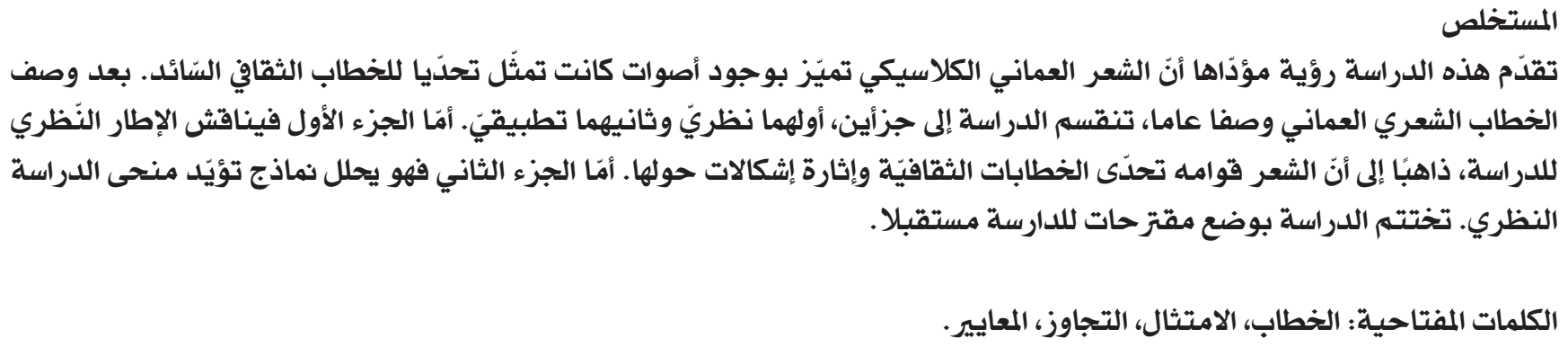




\section{Introduction}

\section{Omani Poetry: an Overview}

Oman is a mainly religious and conservative society (Al Muwafi, 2004, p. 82). Like other societies in the Arabian Peninsula, the tribe plays an important political, social and economic role. Taking his cue from Hofstede (1980[1994], 1983, 1990), Al Balushi (2007) argues that Omani society by and large can be characterized as a large power distance, collectivist, masculine and an uncertainty avoiding society. One manifestation of this is that its public discourse views any deviation from inherited social and cultural norms as a cause for anxiety. Perhaps as a result of this, it has always presented Omani classic poetry as traditional in form and conformist in content.

Throughout Oman's history, poetry, both oral and written, has always enjoyed a special status. Indeed, poetry is admittedly the earliest and the most famous form of scholarship known in Oman (Darwish, 1992, p. 8). The standard Arabic form of QaSiidah has generally been considered the highest form of poetry, and as Ali (1984, p. 216) observes, Omani poetry has always retained the old Arabic single rhyme scheme. After the sixties, however, Omani local poets became increasingly exposed to contemporary Arabic verse and to Western influences, especially English and French. As a result, some poets began to free themselves from the constraints of rhyme and rhythmic patterns, producing a variety of 'free' forms. This, however, has not gone unchallenged. There is reluctance to accept 'free' forms, especially among those with a strong adherence to tradition. Al Bahlani (1996), for example, takes comfort in the idea that Omani poets have always preserved original Arabic poetic form, both formally and thematically. He rejects alternative forms as a negative effect of modern secularism (ibid., p. 12). The likes of AlBahlani go so far as to claim that following modern trends is a mere blind imitation of imported Western literary forms.

However, leading contemporaries take issue with such a characterization. Saif Al Rahbi (1991), a practitioner and champion of 'free' poetry, opposes the likes of Al Bahlani. He argues that modernity is a result of multiple and complex challenges that the Arab world has faced in the modern era. Though free forms have almost superseded the traditional Arabic pattern, the belief that Omani classical poetry is conservative in its ideological orientation is still firm in people's minds. We challenge this and contend that Omani classical poetry deviated from public discourse. Indeed we believe that if poetry merely echoes public discourse it ceases to be poetry. We will argue this point by referring to both literary theory and Arabic poetry itself.

\section{Part One: Theoretical Bearings}

Poetry as Discourse Deviation

Our point of departure is the idea that poetry by nature is a distinctively deviant form of communication, and its distinctiveness drives from how it foregrounds its linguistic constituents.

Taking his cue from Roman Jakobson's 'Closing statement: Linguistics and Poetics,'** Widdowson (1974, 1975, 1983, 1984, 1985, 1988, 1992, 1996, 1998 and 2002) argues that by foregrounding its features, by deviating from the 'normal' standards of communication, poetry imposes on itself another type of regulatory mechanism; it places the deviant features in parallel patterns. The saliently interconnected linguistic items attract readers' attention and assume significance by virtue of their relation with other items within the same work, a significance they would not normally enjoy in the language system. He calls this extra layer of significance 'value' (Widdowson, 1975, p. 33). The reader takes his cue both from what the linguistic constituents mean in language and from the relations established by the patterns (intra-textual relations).

Research in cognitive linguistics supports this view. Cook $(1990,1994)$ argues that poetry functions by virtue of the unique organization of its forms (linguistic and structural). Drawing on Artificial Intelligence, discourse analysis and schema theory, ${ }^{* * *}$ he develops the notion of a 'cognitive change principle' (1994, p. 44), whereby literature refreshes the reader's mind by changing their existing mental representations as regards language, texts and the world at large. He argues that these schemata form a backdrop against which new experiences are processed and measured. If the new schemata help to preserve and reinforce the old ones, then the discourse is 'schema adding'. If the old schemata are disrupted, i.e. if new ones are created or new links are seen in the existing schema,

\footnotetext{
* Literary theory also emphasizes the social and institutional factors that contribute to defining literature. Some theorists emphasize how a given community decides to canonize certain highly valued texts (Herrnstein-Smith, 1978, 1988; Maybin, 1996), how socio-cultural institutions define what literature is (Eagleton, 1983), or how a discourse community defines literature (Fish, 1980). Others such as Fowler $(1981,1996)$ stress the socio-political and institutional determinants of literature.

** This paper has exerted considerable influence on stylistics in particular and on literary theory in general (Abrams, 1981, p. 275; Carter and Simpson, 1989, p. 1; Cook 1994, p. 153; 2001, p. 134; Fab and Durant, 1987, p. 1; and Weber, 1996, p. 1).

*** Cook draws upon research on text linguistics and cognitive linguistics. He examines the works of, among others, de Beagrande and Dressler 1981 , and cognitive linguistics such as Sperber and Wilson 1995 and Schank and Abelson (1977).
} 
then the discourse is characterized as 'schema refreshing' (ibid., p. 191) or discourse deviation* (ibid., pp. 181- 211).

Bearing in mind the view that poetic discourse is by definition a deviant discourse, we will examine in Part 2 how deviant Omani classical poetry is. But to pave the way for such a discussion we need to disentangle some issues around deviation.

First, we have defined poetry as deviant by nature. Now we must ask ourselves if it can be anything but deviation. We will discuss this in relation to Arabic culture. If we consider Arabic poetry and the journey it has undergone from the pre-Islamic period till today, we will see it has always constituted a violation of linguistic, social and religious norms. This is how, for example, the poetry of Imru' al-Qays (497-545), the pre-Islamic Arab poet from the Arabian Peninsula, can be understood. He is referred to in the literature as having "reveled in his poetry" (Ibn Qutaybah, 1982, p. 110). The revelry referred to here is nothing but deviation from the period's social mores. Nevertheless, his revelry didn't prevent the interpreters of the Qur'an from quoting him and placing his lines alongside Qur'anic verses. This suggests that those interpreters understood that poetry goes beyond ideological boundaries. Otherwise, they would have ignored it and would have not gone further than consulting the poetry of Arab poets who lived during or after the Islamic revelation.

That is how we understand Qur'an's stance towards the Prophet being a poet. It vehemently rejects this accusation, which is sufficient evidence that poetry both transcends and penetrates taboos. Indeed a poet can never be a prophet. His task is to transcend not to legislate. This "transcendental" nature of poetry was recognized by an old critic al- Așma'î (740 - ca. 828). He was disturbed by Hassān ibn Thābit (died 674), who began to preach some Qur'anic moral lessons in his poetry. al- Așma'î couldnıt tolerate this and pronounced that "poetry was characterized by gloominess and vice. If it entered in the domain of virtue it would automatically lose its defining quality. Though Hassan is a pre-Islamic giant his poetry suffered as Islamic revelation came» (Ibn Qutaybah, 1982, p. 305). In a similar vein, we can take the stance of the great companion, the one who is renowned as "the sea» for his vast knowledge, Abd Allāh ibn 'Abbās (d. 688) on the poetry of 'Umar ibn Abī Rabī'ah (644-711), who desecrated ethics and conventions in his insolent love poetry. Different historical sources report that he wooed with his poetry every woman travelling either for 〈haj〉 or 〈Omra〉 (al-Așbahānī, 1992, p. 181). Consider the following two lines:

Madly she went tracing me

Asking those walking around the Ka'aba about Omar (Ibn Abī Rabī‘ah, 1983, p. 139).

Notwithstanding this deviance from norms, he is regarded highly by the companion of the Prophet, Abd Allāh ibn 'Abbās, who it can be inferred was aware of the deviant nature of 'Umar's poetry.

During the Abbasid Period, we note that poetic deviance was exhibited in the "al-muwallidīn" poets, who were led by Abū Tammām (808-842). He insisted on the definition of poetry in following dramatic terms:

Poetry is a vulva

Long is the night for the one

Who deflowers it (Abū Tammām, 1983, p. 350).

We can notice that Abū Tammām goes beyond seeing poetry as merely "rhythmical and rhymed". Indeed it has become a 'vulva' whose secrets are unknown except for the deflowerer.

Second, there seems to be an impression that deviating from norms or breaking taboos is an aspect of modernism. We understand that 'modernism' at base is a moment of tension in dominant linguistic or cultural structures. As such it is not exclusive to any period. Adūnīs, the contemporary Arab poet and critic, says in his "Manifesto of Modernism" that the modernity of a poetic text "is not necessarily consistent with a particular period. When we are moved by the poetry of, say, Imru' al-Qays or al-Mutanabbī (916965) or Abū Tammām, that is not because it is a manifestation of a glorious past but because it is creative, and as such represents a moment that breaks through periods. "Creativity is an everlasting presence, and as such it is an everlasting conversation". (Adūnīs, 1993, p. 22). On that basis an Omani 'modern' poet could be Sulaymān ibn Sulaymān al- Nabhānī (d. 1494) or Aḥmad ibn Sa'îd al-Satālī (1163-1255) or Rāshid ibn Khamīs al-Habsī (1678-1737), despite the fact that they lived in bygone periods. And on the same basis we do not take a modern poet such as Suleiman ibn

* This raises the question whether discourse deviation is a universal characteristic of literature or whether it is a post-modern Western concept. This notion has been problemam tized in different ways (cf. Jeffries, 2001; Semino, 1997, 2001; and Stockwell, 2002).

** His admiration of 'Umarıs poetry is documented in several literary sources. See for examples: (al-Așbahānī, 1992, p. 22; al-Irbilī, 1987, p. 4; Mubarrad, 1956, p. 3). 
Khalaf 'al-Kharūșī or Abū Mu'ādh al-Khașībī (19592012) or Sa'îd al-Sạqlāwī (b.1956) or their contemporaries. In other words, poetry's modernity does not stem from a period or current moment, nor does it stem simply from treating modern subject matter. There may be a poet writing on man ascending the moon, but his poem might come across as banal and with no trace of creativity. Conversely, another poet might write on riding camels but his poem might brim with novelty and briskness.

Finally, deviation is not exclusively connected with free poetic form, as some think. A prose poem or one following an unrhymed rhythmic pattern may not necessarily be modern, if it does not challenge readers' assumptions about life and the universe. On the other hand, a poem rhymed and traditionally patterned rhythmically could come across as causing tension. In the Abbasid period, Abū al-'Atāhiyah (747-826) was not labeled "modern" though he consistently deviated from traditional rhythmic pattern. Meanwhile Abū Tammām was taken to be the spearhead of the "modernists", though known for his strong commitment to those patterns and had never deviated from them. Hence, we would like to reemphasize that some Omani classical poets were more 'modernist' than the conformists who live among us today.

We will now provide examples taken from classical Omani poetry.

\section{Part Two}

Omani Classical Poetry as a Deviant Discourse Indeed the title of this section might surprise many, as there's widespread view that Omani poetry has always dealt in a conformist manner with such issues as religion, politics and history. Researchers might wonder why it has always revolved around these issues and why local critics have examined them almost to saturation point, while issues such as sex and drink have received short shrift or been completely ignored. This might be partially attributed to the fact that poetry in Oman has been compiled, and sometimes, interpreted by historians of literature who followed a rather rigorous religion based methodology as they wanted to maintain standards of taste and decency. More broadly, society has always exercised a fierce censorship on such topics, thus developing taboos even against thinking about them, let alone researching them.
Nevertheless, we contend that, strange as it may appear, Omani society in the past challenged the ferocity of the taboos far more than is currently thought. There are voices in classical poetry that did not conform to the dominant ethos. Indeed, as we shall, some such non-conformist poets enjoyed great prestige, scientifically, socially and religiously. We will examine both the manifestations of taboos in Omani poetry and the strategies poets employed to break them.

We will try to substantiate our claim by discussing some examples. We classify deviance into two major kinds: social and religious, though this is purely for analytical purposes, as in reality the two overlap.

\section{Deviation from Social norms}

We said in Part 1 that Omani society is conservative and masculine. The dominant cultural discourse presents the image of man as a powerful, strong, courageous and respectful. He is expected to show his respect for, among others, women, and play his 'manly' part as father, brother or husband. As such, acts of playfulness and courtship are forbidden, let alone their public expression. However, if we examine the poetry of major Omani poets we see that publically through poetry, they celebrate playfulness. And what is of special interest is that clergy, tribal leaders, the blind and healthy display an equal share of deviance in this regard.

An interesting case is Sa'īd ibn Muhammad Al-Kharūṣī, known as al-Ghashrī, (the second half of the eighteenth century), whose verse is known for its moralistic and ascetic aspects. In his description of his beloved, he says:

Shakes and shivers her rump when she walks

The wise, seduced by her, go crazy

With moans and murmurs (Al-Kharūșī, 1981, p. 216). Hamīd ibn Hamad ibn Ruzayq, (1783-1874), a wellknown Omani historian, offered the boldest and liveliest painting of women's charms and beauty. For example, he went to great lengths to describe her curves. Indeed, he succeeded in making us feel as if he was, as it were, spying them in narrow corridors, as is in the following lines:

The coy lady,

If the veil she takes off

The night flies and the day cheers

Sways she like a twig

\footnotetext{
* We should emphasize that our main concern lies on how poetry is a culturally deviant discourse. It follows that a detailed account of how deviance occurs in cognitive terms falls outside our remit.
} 
Swing little pomegranates on her chest

The griddle on her graceful waist widens

And the loincloth on her rump tighten

For her plump forearms

Too small are her bangles

Her eyes all sins shelter

Her wavy body ensnares

Even the sober (Ibn Ruzayq, 1983, p. 38).

Both al-Ghashrī and ibn Ruzayq could actually see women. And yet, there is a controversial blind poet who could describe female beauty with equal vividness. Rāshid ibn Khamīs Al-Habsī lost his sight when he was six months old. Despite that, however, his depiction of the female body is lush with minute details caught by the eye of a creative artist, as is clear in the following lines: |

Adorned with

A proud nose

A graceful neck

A handful breast

And rump that lead the devout astray

And seduces the ascetic worshipper (Al-Habsī, 1982, p. 126).

No less bold, we see Abu Al Ahwal Al Darmaki (17451809), a poet with a strong religious background, writing about the physical and sensuous aspects of his beloved in a markedly straightforward manner. He says:

Shyly flaunts the deer child

Like the sun before its rise

Tender and warm-hearted

Though still intoxicated by her saliva

She still seeks me to sip more and more

No other way is there to pluck

The rose of her juicy cheeks

Except to shower her with more kisses

And ravish her with more love bites (al-Hajri, 2013, p. 160).

Among the strategies Omani poets used to break the taboos and challenge their hold was to insert into their poems (even eulogies and elegies) moments of frivolous and licentious fun. And this is an aspect in which both the lay and the religious have an equal share. We see this in the likes of Al Sheikh Ahmad ibn al-Naz̧ar (the first half of the twelfth century), Judge Manșūr ibn Nasir Al-Farsi (1895-1976) and AlSheikh
'Abd Allāh ibn 'Alī Al-Khalīīi (1922-2000) together with Ibn Ruzayq, Ibn Shaykhan al-Salimi (1868-1927), Mūsá ibn Ḥusayn Ibn Shawwāl al-Kĩdhāwī (d. 1623) and Hilāl ibn Sa'îd ibn 'Urābah (1805-1862). It is immaterial whether those moments are real or imaginary. What matters is that they represent a bold poetic discourse that is heedless of the authority of social decorum. Sheikh Ahmad ibn al-Naz̧ar, a revered scholar in the $6^{\text {th }}$ Al Hijrah century, describes a passing of moment playfulness in the following way.

Pillowing my head on my arm,

I look at my bedmate, Sulaima

When the night falls

My desire rises and fiery I become

For still is sharp the edge of my sword (Ibn al-Nazar, 1980, p. 138).

It could be argued that Sheikh Manșūr ibn Nasir alFarsi, a judge and Islamic scholar, is the boldest in this regard. So vivid are the descriptions of his beloved's charms that one imagines that he lived in the Abbasid Period with all its playful frivolity. Listen to him rejoicing here:

Her bosom shines with a lovely sheen

Like the sun in a silvery plate

In a day cloudless

Her breasts like two silvery goblets

Gracefully fixed like nails on the marble

And gentle slender abdomen

A delicate slim waist

That stands conversely with her rump

I dally with her, kiss her, hug her

She relishes that but coquettishly declines

At times I smell her fragrance and at times I suck

Her tongue and then her saliva glides down.

Close to me I at times draw her

She snake-like bends and curves

'Gently, I am hurt', she says

You, my reproacher, don't chide me

Madly my heart craves for her (al-Farsi, 1992, p. 215).

With the same audacity, we find 'Abd Allāh ibn 'Alī al-Khalīi , a poet with a strong religious background, giving free rein to his imagination when describing playful moments with his beloved, whom he used to meet and drink by a stream:

By the stream I drank the cup of love

She came drunk mixing her cup with mine I flirted with her and she at first drew back All is fair in love 
Then pleased she was when drunk I kissed her lips and tongue

I sucked from her aroma

Don't you smell musk on my breath?

I touched her two breasts while the guards were mindless

I passed my fingertips over her waist

Peace of warmth flowed in my breath (al-Khalīlī, 1990, p. 387).

In another poem, we see the sheikh even bolder and more audacious as he gives advice to lovers, mentioning minute subtleties of love:

If you met your beloved

Express yourself in all ways

Sip her lips and suck her saliva

Take off her clothes after hugging and kissing her

Pluck the roses of her cheek

With a wet tear

Bite on top of her twig

The pampered breasts

And tear apart the necklace threads

Strew them hastily

Humble the wine of love

By pouring it into her mouth

Sing for her the melody of love

After you're done with kissing her (p. 372).

Ibn Ruzayq is perhaps the boldest example available. Indeed it could be argued that his poetry intersects with that of Abū Nuwās (756-810), the poet of "playfulness and buffoonery", as described in the histories of Arabic literature (Dayf, 1966, pp. 220-237). Listen to him in the following passage in which he describes a moment of his friskiness:

So lovely, so gorgeous is she

Bewildered is the wisest and stunned the most eloquent

If the infidel sees her he kneels glorifying God

I shower upon her the wine

That was imprisoned in the cask

The heaven of cheek was my prize when I kissed her

And the heaven of river when I drank from her mouth How beautiful is the rose under her mantle

It yellowed when I tried to kiss it (Ibn Ruzayq, 1983, p. 33).

Sometimes we see him describe his beloved's saliva as a substitute for the wine that she made him drink in the previous poem.

Such a girl who if she bends her body

Every branch of it bends

Such a wine we have

If wine saw it will leave its cask

Such a morning she gave me that it veiled the night

So at night and in the morning my heart went mad

So with no wine we drank and went crazy

But what intoxicated us was

The nectar if anyone drank

He'll never be sad

A hug that ran from the mouth to the sole

So both the mouth and the sole were happy

A time that glistened with happiness

And the heart got what it desired (Ibn Ruzayq, 1997, p. 157-158).

In the $16^{\text {th }}$ century, we find Mūsá ibn Hụsayn ibn Shawwāl, known as al-Kīdhāwī, describing his own special moments of love making saying:

We kept drinking from the morning till night

Remembering our old memories

If you saw us you'd see

The crescent hugging the full moon

From her hand and mouth she passes to me

Ember and wine as she wishes

So the breeze of my youth blows gently

And the stars of my boyhood rise luminously (alKīdhāwī, 1985, p. 144).

Ibn Shaykhan al-Salimi, a highly esteemed scholar with a prestigious social position, describes his rendezvous with his beloved in a gentle yet bold way:

She hugged me and our necks met

My lips twisted and turned over her cheeks

She bent if I gently pressed her body

And smiled if I kissed her mouth

And brought her face and cheek closer

If I wanted to kiss her.

My bedmate she became when the tattler was unaware

And thus I sipped more and more from her lips (Ibn Shaykhan, 1995, p. 240).

One of the most important poetic texts is by the great Omani poet and Islamic scholar and judge, Abū Muslim al-Bahlānī (1860-1920). This a text in which he goes to great length in exploding every possible taboo 
in a clear bold language.

My entire life

I give to a tender playful girl

With whose lips I dallied

I gave her cups of tea

Said she "Is this the taste of nectar?"

The cup in her hand and mouth

Like an agate in an agate in agate

She said playfully and merrily

"Do you turn away from my saliva to tea?"

Said I "My dearest wake up

With your saliva my flame of fire will die"?

She brought her mouth closer to me and said

"Take pleasure in me till dawn"

So I began to suck the rose of her cheeks

And sip the ember of her luminous mouth.

When she led me astray

I began to cry "Oh! Show me my way, my Guide!" (Ibn

'Udayyim, 1986, p. 493)

This is how Omani poetry persistently breaks all taboos and gives precedence to the poetic spirit that dies if enchained.

\section{Deviation from Religious Norms}

We said in Part 1 that Omani society is religiously conservative. A major manifestation is that alternative interpretations of Islam are not accepted, as the distinction between what is holy and what is unholy is considered sharp. The predominant, officially sanctioned discourse would avowedly abide by that distinction. However, poetic discourse challenges it. We see poets using religious words for purposes that in fact defy religion, or treating religious subjects such as love of God, using 'irreligious' words. The use of 'wine' is a case in point. Poems, even those treating different subject matter, include a description that arguably outshines poets famous in the Arab World for wine verse, such as 'al-'A'shá (d. ca. 629), Bashshār ibn Burd (d. 783) and Abū Nuwās (756-810). Indeed al-Nabhānī (d. 1494), al-Satālī (1163-1255), al-Ḥabsī (1678-1737) and Ibn Ruzayq (1783-1874) left lines or even complete stanzas carrying rather subtle descriptions of wine and drinking parties. We find description of wine that verges on sanctification in the poetry of Sulaymān ibn Sulaymān al-Nabhānī. He says

Such a wine if spelled and glittered Its worshippers would kneel up to their chins So it resounds in the cask
Bring it Aba Ishāa pure and red

Like gold it shines in the jug

Amongst familiar youth

Pure-bred and noble

Drank they together

With dignity and grace (al-Satālī, 1980, pp. 23-24).

He describes his drinking companions who apparently were the elite of Omani society at that period.

I start the party of pleasures with

White faced, open handed noble men

I pour them wine from a jug

If mixed with water sparks will scatter from its sides

There're nights in which stars disappear

And darkness spreads across

I alarm everyone whose head begins to droop

Out of drunkenness or drowsiness (al-Satālī, 1980, p. 202).

Indeed it could be argued that al-Satālī excels Abū Nuwās both in the diction and figures of speech that he uses in describing wine, as is the case in the following lines:

In such a sparkling manner

It falls through the mouth of the cask

As a star swooping down in a cup.

We wish to drown our sorrows in wine

But drowned are we in yearning

For the face of a beloved or homeland (al-Satālī, 1980, p. 49).

The blind poet Rāshid ibn Khamīs al-Habsī is possibly the most transparent and most honest in directly and openly announcing that he drinks:

I adore sipping the wine

Energizes it my body, delights it my soul.

So delicious that if the stammerer tasted

He would be so eloquent (al-Ḥabsī, 1982, p. 327)

And we see him proclaiming wine, claiming it has its own special nature and philosophy:

The daughter of grape and palm

So purebred is the wine

Neither is it belittled by drunkenness

Nor by the different taste

Fair it is to all drinkers

The chivalrous and the mean (al-Habsī, 1982, p. 457). 
Another strategy that Omani poets used to deviate from the officially sanctioned religious discourse is what is known as "defiling the holy", which involves removing such religious terms as "prophets" and "alKa'bah" from their original contexts and using them in non-religious associations. Though used to a small degree, it was noticeably employed by Abū Muslim al-Bahlānī, Ibn Shaykhan al-Salimi, al-Kīdhāwī, alGhashrī, Aḥmad ibn al-Naz̦ar, Manșūr Al-Farsi and Sa'īd ibn Khalafān al-Khalīī (1815-1870). All these are highly esteemed names in Omani cultural discourse.

Abū Muslim says in one of his poems:

For you I squeezed the purest

From the wine of Allah

Never is drunkenness a sin

Die then with it

Indeed the virtuous before us went astray

And roamed amidst the people intoxicated

You see them drunk

People spread their knowledge

And the subtle light shrouds it in the sea of blindness I filled my cup with graceful wine

And moved my chords and made the mute talk (Ibn 'Udayyim, 1986, p. 274).

He says in another poem:

Is there's anyone like me?

This wine is my wine

The prophets are my drinking companions

Before me Ibrahim, the Friend of God, and Moses

Fell desperately in love with it

And then Jesus and the Prophet

This is my state and this is my position

Then know me and ignore my gratitude (1986, p. 274).

It is true some of these terms such as "the wine of God", "al-'irfān", "the drinking companions" are old Sufi strategies used by the likes of al-Suhrawardi (1153-1191), Ibn al-'Arabī (1165-1240) and al-Ḥallāj (859-922). But what we are trying to suggest is that these words have been taken away from their original contexts, thus giving the poets a chance to combine sacred words such as "Allah" and "prophet" with profane ones such as "wine", and "drinking companions".

Another example, Ibn Shaykhan al-Salimi, while praising his beloved says:

In the pulpit of these cheeks there's a point Around the kaba of its beauty people thronged
As if we received the Black Stone

But with eyes was the reception (Ibn Shaykhan, 1995, p. 145).

Clearly, Ibn Shaykhan in these poems is not talking about the Haj pilgrimage or al-'umrah meetings. He's rather talking about his beloved, picturing her cheek as "The Black Stone". Here is the defiling of the sacred is manifest, as holy words are transferred into the context of love poetry, al-ghazal. This is undoubtedly a strategy that challenges the hold of taboos, at least in poetic terms.

Through these examples we can see that Omani poets did not always toe the dominant discourse line. Indeed they deviated from it challenged it, dealt with taboos using diverse strategies.

\section{Conclusion}

We argued that, historically, contrary to what is generally thought, Omani classical poetry deviated from the norms of the dominant discourse. It broke taboos within both the social and religious domains. We would like to conclude by putting forward suggestions for further study. We have touched on an area of research that has hardly ever been dealt with before. As such our paper raises more questions than it answers. On the theoretical level, it has to be researched further whether the deviation of Omani poets stemmed from following an age old Arabic poetic tradition whereby a poet would start wooing his beloved with all manner of daring metaphors before getting down to his main theme. Also, we have tried to substantiate our argument with selected lines. It would be worth establishing if it holds true when applied to complete poems.

\section{Arabic References:}

Abū Tammām, H. 1983. Dīwān 'Abī Tammām bi-Sharḥ 'al-Khațīb 'al-Tibrīzī ; taḥīq Muhammad 'Abduh 'Azzām. vol. 2. al-Qāhirah : Dār al-Ma'ārif.

Adūnīs, A. 1993. Al- bayānāt; qaddama la-hā Muḥammad Luții al-Yūsufi. al-Baḥrayn : Usrat alUdabā' wa-al-Kuttāb.

al-Asḅahānī, A. 1992. al- Aghānī; tahq̣īq Samīr Jābir. vol. 1. Bayrūt : Dār al-Kutub al-'Ilmīyah.

al-Bahlānī, Y. 1996. al- Shi'r al-'Umānī al-mu'āșir. alQāhirah : Dār al-Bayān.

al-Farsi, M. 1992. Sumūț al-farā’id fi nuhụ̄r al-ḥisān alkharā'id. Muscat: Maktabat al-Dhamri. 
al-Ḥabsī, R. 1982. Dīwān al-Habsī ; taḥīq 'Abd al'Alīm 'T̃sá. Muscat : Wizārat al-Turāth al-Qawmī wa-alThaqāfah.

al-Ḥajarī, H. 2013. Hadāthat al-aslāf: Iḍāāàt min alShi'r al-'umānī al-qadīm. Muscat: Kitāb Nizwá.

Alī, A. (1984). al- Shi'r al-'umānī. al-Qāhirah : Dār alMa'ārif.

Al-Irbilī, A. 1987. al- Tadhkirah al-fakhrīyah; tahq̣īq Nūrī Hạmmūdī al-Qaysī, Hạ̄tim Sạ̄lih.al-Dạ̄min. Bayrūt : 'Ālam al-Kutub.

Al-Khalīī, A. 1990. Dīwān waḥy al-'abqarīyah. Muscat: Wizārat al-Turāth al-Qawmī wa-al-Thaqāfah.

Al-Kharūṣī, S. (1981). Dīwān al-Ghashrī; taḥqīq Muḥammad 'Abd al-Mun'im Khafājī. Muscat: Wizārat al-Turāth al-Qawmī wa-al-Thaqāfah.

al-Kīdhāwī, M. 1985. Dīwān al-Kīdhāwī. Muscat: Wizārat al-Turāth al-Qawmī wa-al-Thaqāfah.

al-Nabhānī, S. 1965. Dīwān al-Sulțān Sulaymān ibn Sulaymān al-Nabhānī; taḥqīq 'Izz al-Dīn al-Tannūkhī. Dimashq : al-Mațba'ah al-'Umūmīyah.

al-Raḥbī, S. 1991. Dhākirat al-shatāt. Bayrūt: Dār alFārābī.

al-Satālī, A. 1980. Dīwan al-Satālī; tahq̣īq 'Izz al-Dīn al-Tanūkhī. Muscat : Wizārat al-Turāth al-Qawmī waal-Thaqāfah.

Darwīsh, A. 1992. Madkhal ilā al- Shi'r al-'umānī. alQāhirah : Dār al-Uqșur.

Dayf, S. (1966). Tārīkh al-adab al-'Arabī : al- 'Așr al'Abbāsī al-awwal. al-Qāhirah : Dār al-Ma'ārif.

Ibn Abī Rabī'ah, U. 1983. Sharh diwan 'Umar ibn Abī Rabī'ah ; taḥqĩq Muḥammad Muḥyī al-Dīn 'Abd alHamīd. Bayrūt: Dār al-Andalus.

Ibn al-Naẓar, A. 1980. Kitāb al-da'ā'im. Muscat: Wizārat al-Turāth al-Qawmī wa-al-Thaqāfah.

Ibn Qutaybah, A. 1982. 'al -Shi'r wa-'al-Shu'arā'; taḥqīq wa-sharh 'Aḥmad Muḥammad Shākir. vol. ı. alQāhirah: Dar 'al-Ma'arif.

Ibn Ruzayq, H. 1983. Dīwān Ibn Ruzayq; taḥqīq Muḥammad 'Abd al-Mun'īm Khafājah . Muscat : Wizārat al-Turāth al-Qawmī wa-al-Thaqāfah.

Ibn Ruzayq, H. 1997. Silk al-farīd fi madḥ al-Sayyid alḤamīd Thuwaynī ibn Sa'īd; taḥqīq Muḥammad 'Alī al-Ṣulaybī. vol.3. Muscat: Wizārat al-Turāth al-Qawmī wa-al-Thaqāfah.

Ibn Shaykhan, M. 1995. Dīwān Ibn Shaykhan. jama'ahu Muhammad 'Abd Allah al-Salimi ; raja'ahu 'Abd alSattar Abū Ghuddah. al-Qāhirah : al-Majmū'ah alȘuḥufiyah lil-Dirāsāt wa-al- Nashr.

Ibn 'Udayyim, N. 1986. Dīwān Ab̄̄ Muslim Nāsịr ibn Sālim ibn 'Udayyim al-Rawāhị shā'ir zamānihi wafarīd awānih ; tahg̣īq 'Abd al-Raḥmān al-Khazendar.
Dimashq : Dār al-Mukhtār.

Mubarrad, M. 1956. al- Fāọil; taḥqīq 'Abd al-'Azīz alMaymanī. al-Qāhirah : Dār al-Kutub al-Mi.

\section{English References}

Abrams, M. H. 1981. A Glossary of Literary Terms. Dunedin. University of Otago.

Al Balushi, K. M. 2007. The Use of Translation in Teaching Poetry: A Theoretical Exploration, with Special Reference to Oman. University of Nottingham.

Al Muwafi, M. 2004. Oman: the Construction of the Modern State. Qalyoob: Mutba: Al Tijariyya.

de Beaugrande, R. and Dressler, W. 1981. Introduction to Text Linguistics, London: Longman.

Carter, R. A. and Simpson, P. 1989. 'Introduction', in R. A. Carter and P. Simpson (eds.) Language Discourse and Literature: An Introductory Reader in Discourse Stylistics (pp. 1-20). London: Unwin Hyman.

Cook, G. 1990. A Theory of Discourse Deviation: the Application of Schema Theory to the Analysis of Literary Discourse. Unpublished PhD Thesis. University of Leeds.

Cook, G. 1994. Discourse and Literature: The Interplay of Form and Mind. Oxford: Oxford University Press.

Eagleton, T. 1983. Literary Theory: An Introduction. Oxford: Basil Blackwell.

Fabb, N. and Durant, A. 1987. 'Introduction: the linguistics of writing: retrospect and prospect after twenty-five years', in N. Fabb, D. Attridge, A. Durant, and C. MacCabe (eds.) The Linguistics of Writing: Arguments between Language and Literature. Manchester: Manchester University Press.

Fish, S. 1980. Is There a Text in This Class? The Authority of Interpretive Communities. Cambridge, MA: Harvard University Press.

Fowler, R. 1981. Literature as Social Discourse: The Practice of Linguistic Criticism. London: Batsford.

Fowler, R. 1986. Linguistic Criticism. Oxford: Oxford University Press.

Herrnstein-Smith, B. 1978. On the Margins of Discourse: The Relation of Language and Literature. Chicago and London: Chicago University Press.

Herrnstein-Smith, B. 1988. Contingencies of Value: Alternative Perspectives for Critical Theory. Chicago: Chicago University Press.

Hofstede, G. (1980. reprinted in 1994). Cultural Consequences: International Differences in Work-related Values. Newbury Park: Sage Publications.

Hofstede, G. 1983. 'The cultural relativity of organisational practices and theories', Journal of International Business Studies, 83, 75-89. 
Hofstede, G. 1990. Cultures and Organizations: Software of the Mind. London: McGraw Hill.

Jakobson, R. 1960. 'Concluding statement: linguistics and poetics', in T. A. Sebeok, (ed.) Style in Language (pp. 350-77). Cambridge, MA: M.I.T. Press.

Jeffries, L. 2001. 'Schema affirmation and white asparagus: cultural multilingualism among readers of texts', Language and Literature, 10 (4), 325-343.

Maybin, J. 1996. 'An English canon', in J. Maybin and N. Mercer (eds.), Using English from Conversation to Canon (pp. 235-74). London: Routledge.

Semino, E. (1997). Language and World Creation in Poems and Other Texts. London: Longman.

Semino, E. 2001. 'On reading, literariness and schema theory: a reply to Jeffries', Language and LiteraturE, 10(4), 337-355.

Schank, R. and Abelson, R. 1977. Scripts, Plans, Goals and Understanding, Hillsdale, NJ: Lawrence Associates.

Sperber, D. and Wilson, D. 1995. Relevance: Communication and Cognition. Oxford: Basil Blackwell.

Stockwell, P. 2002. Cognitive Poetics: An Introduction. London: Routledge.

Weber, J. J. 1996. 'Towards contextualized stylistics: an overview', in J. J. Weber (ed.) The Stylistics Reader: From Jakobson to the Present (pp. 1-8). London: Arnold.

Widdowson, H. G. 1974. 'Stylistics', in J. P. B. Allen and S. P. Corder. (eds.) The Edinburgh Course in Applied Linguistics, 111: Techniques in Applied Linguistics (pp. 202-31). Oxford: Oxford University Press.

Widdowson, H. G. 1975. Stylistics and the Teaching of Literature. Harlow: Longman.

Widdowson, H. G. 1984. 'Reference and representation as modes of meaning', in H. G. Widdowson. Explorations in Applied Linguistics 2 (pp. 150-59). Oxford: Oxford University Press.

Widdowson, H. G. 1985. 'The teaching, learning and study of literature', in R. Quirk and H. G. Widdowson. English in the World: Teaching and Learning the Language and Literatures (pp.180-94). Cambridge: Cambridge University Press.

Widdowson, H. G. 1986. 'The untrodden ways', in C. J. Brumfit and R. A. Carter. (eds.) Literature and Language Teaching (pp.133-39). Oxford: Oxford University Press.

Widdowson, H. G. 1988. 'Poetry and Pedagogy', in D. Tannen (ed.) Linguistics in Context: Connecting Observation and Understanding. Norwood, NJ: Ablex. Widdowson, H. G. 1992 Practical Stylistics. Oxford: Oxford University Press.
Widdowson, H. G. 1996. 'Stylistics: an approach to stylistic analysis', in J. J. Weber. (ed.) The Stylistics Reader: From Jakobson to the Present (pp. 138-148). London: Arnold.

Widdowson, H. G. 1998. 'Reading the signs. The critical interpretation of texts', SPELL: Swiss Papers in English Language and Literature, 11, 145-159.

Widdowson, H. G. 2000. 'Critical practices: on representation and the interpretation of texts', in S. Sarangi and M. Coulthard. (eds.). Discourse and Social Life. London: Pearson Education.

Widdowson, H. G. 2002. 'Verbal art and social practice: a reply to Weber', Language and Literature, 11 (2), 161-167. 